DOI: $10.22616 /$ REEP.2020.034

\title{
Discovering a Sustainable Mindset in Hospitality Educators
}

\author{
Sandra Iriste ${ }^{1}$ Dr.paed.; Anne Fox ${ }^{2}$ \\ Latvia University of Life Sciences and Technologies, Latvia ${ }^{1}$ \\ Norwegian University of Science and Technology (NTNU), Norway ${ }^{2}$ \\ sandra.iriste@gmail.com ${ }^{1}$; anne.e.m.fox@ntnu.no ${ }^{2}$
}

\begin{abstract}
One of the main tasks of modern university professional education is to develop the sustainable mindset of future specialists. The development of a sustainable mindset within the study process can be achieved by combining professional competences with sustainability competences. The aim of this study was to promote a sustainable mindset in hospitality educators using a developed blended learning course. The content analysis method was used to discover changes in the hospitality educators' mindset through learning journals and compared to three documents related to sustainability education. Learning journals of nineteen participants, recruited all over the world, were used to generate graphical representations. Results showed that educators' learning journals are a rich source of feedback on the efficacy of the blended learning course "Discovering a sustainable mindset for future-oriented professionals in guestoriented businesses" and can be used as a part of the quality assurance process to improve the course.
\end{abstract}

Keywords: sustainable mindset, hospitality educators, content analyse, learning journals.

\section{Introduction}

Nowadays, hospitality has turned its focus onto sustainability as it relates to business optimization and development, including the environmental, economic and social domains impact. All three domains are closely connected (Figure 1) and interact with each other (Figure 2): problems in one of them will affect the other two domains, and moreover, may have an impact not only on current but also on future generations. In addition, specific focus on one area will lead to an imbalance, the so-called sustainability Mickey Mouse model (Figure 3).

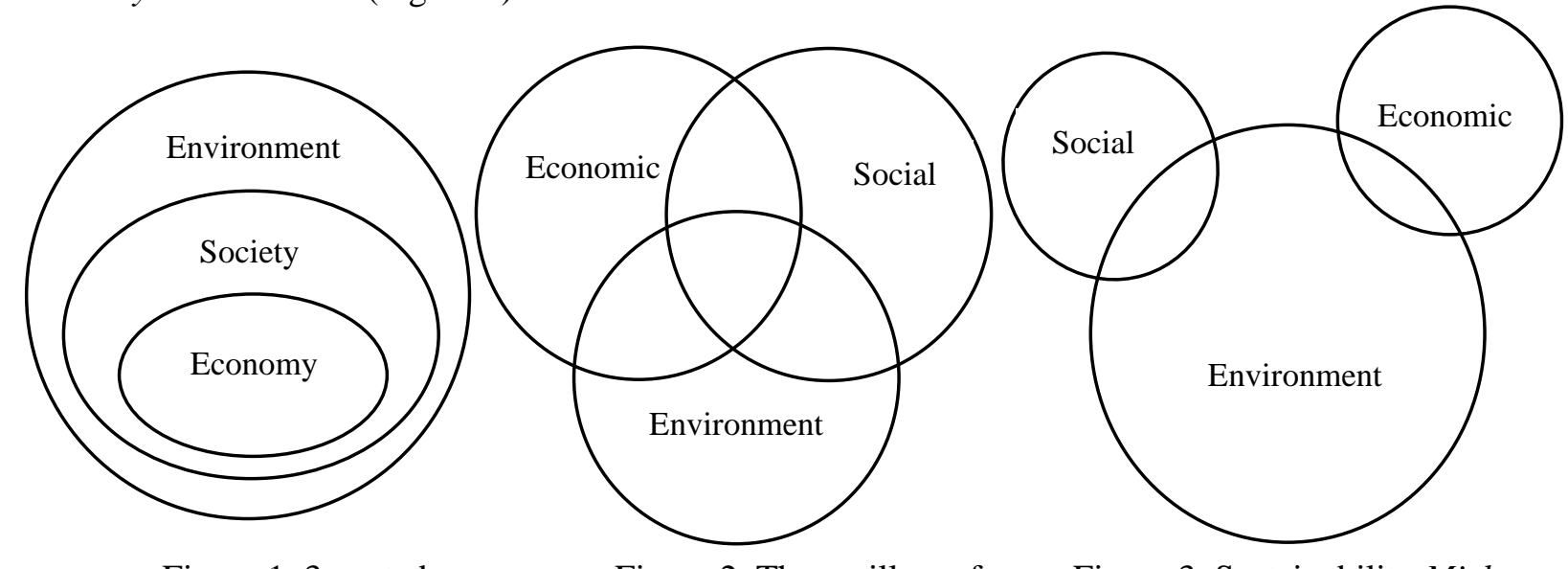

Figure 1. 3-nested dependencies model (Ott, 2003).
Figure 2. Three pillars of sustainability model (O’Riordan, 1997).
Figure 3. Sustainability Mickey Mouse model (Peet, 2009).

Education is a powerful tool for promoting the sustainable development of contemporary society. At the same time, only education that meets the needs of society now and in the future can be sustainable. One of the main tasks of modern university professional education is to discover the sustainable mindset of future specialists. The development of a sustainable mindset within the study process can be achieved by combining professional competences with sustainability competences (Learning for the..., 2012); a separated approach does not lead to the necessary links of knowledge, skills, values and collaboration.

In order to promote a sustainable mindset, both in educators and hospitality professionals, a blended learning course "Discovering a sustainable mindset for future-oriented professionals in guest-oriented businesses" within the EU ERASMUS+ ProfESus project was developed. It consisted of an introductory Module 1, face to face over a week, followed by two online modules: Module 2, comprising 7 units over 8 weeks exploring 
how Green Pedagogy can facilitate development of sustainability competences, and Module 3, the planning and executing of a series of lessons over 5 weeks, and Module 4, the final face to face week, in which participants assessed their project lessons and made plans for their future practice in their classrooms.

The aim of this study was to promote a sustainable mindset in hospitality educators using the developed blended learning course.

\section{Methodology}

The content analysis method was used to discover changes in the hospitality educators' mindset through learning journals compared to three documents related to sustainability education: Future Fit (Sterling, 2012); Learning for the Future (Learning for the..., 2012); Green Pedagogy (Green pedagogy..., 2018). The learning journals were used as a part of 8 ECTS blended learning course for a number of reasons:

- $\quad$ source of feedback on course quality;

- source of self-evaluation;

- source of evidence of a change in the mindsets of course participants.

The content analysis was based on the use of the Leximancer content analysis software. It analysed which concepts are close in meaning within the text in order to develop multi-word thesaurus, and also how closely they are related. This software has earlier been used to analyse learning diaries (Letch, 2012).

The type of data was the written text of the learning journals. There was no limit set for the length/brevity of the text of each learning diary entry.

In the first six month of 2018, 35 participants, recruited globally, took part in the research. They were required to keep learning diaries for the first 14 weeks (representing nine entries and three modules) of the blended learning course. Participants were guided in what to write about in their learning journals with questions relating to the module or unit it was included in, however participants were always free to write about whatever they thought was relevant. The learning journals were not visible to the other course participants.

\section{Results and Discussion}

The concept of sustainable mindset has different interpretations:

- a particular way of thinking: a person's attitude or set of opinions about something (MerriamWebster dictionary, 2016);

- synonymous with innovative mindset (Harris, 2018);

- a set of rules, agreed by a group of professionals as a basis for their professional practice (Kuhn, 2012);

- a way of thinking and being based on broad understanding of the ecosystem manifestation and personal values; embodies the dimensions of values (being) and knowledge (thinking) expressed in actions or competences (doing) (Kassel, Rimanoszy, Mitchel, 2016).

Summarizing the above mentioned, sustainable mindset is a set of rules (often - unwritten), attitudes, values that promote to act automatically, by default, particularly in the work environment. At the same time, a sustainable mindset is not just a result; it is a continuous process as awareness of sustainability is constantly changing.

Since mindset as well as sustainability are rather elusive concepts, indicators of professional and sustainability competences with a lower or higher degree of difficulty (dimensions of competences) within the ProfESus project have been evolved to record changes in participants' learning journals (Laufenberg-Beermann et al., 2019). The list of competences can be amended to keep it up to date.

Analysis of the scientific literature shows that there are different ways in which researchers refer to sustainability competence dimensions:

- orientation, knowledge, behaviour (Cseh, Davis, Khilji, 2013);

- cognitive, metacognitive, motivational (Story et al., 2014);

- head, soul, heart (Sterling, 2011) or head, heart and hands (Scharmer, Kaufer, 2013). 
S. Sterling's (Sterling, 2011) holistic approach to transformative learning for sustainability combines innovative and systemic dimensions, as well as a spiritual dimension related to epistemological learning paradigm change. While this conceptualization applies specifically to higher education, it is closest to ProfESus' sustainable mindset model (Laufenberg-Beermann et al., 2019).

To discover a sustainable mindset in hospitality educators', four dimensions of competence have been adopted from UNECE document (Learning for the..., 2012) within the ProfEsus project:

- Knowledge: Professionals are able to know...

- Skills: Professionals are able to do ...

- Collaboration: Professionals are able to work with others ...

- Values: Professionals are someone who ...

Ultimately hospitality educators and professionals have to be able to plan, decide, act, discuss, transform and reflect on their professional work in a sustainable manner.

Thirty-five participants enrolled on the blended learning course "Discovering a sustainable mindset for future-oriented professionals in guest-oriented businesses". Twenty-four completed the course, but learning journals of only nineteen participants were used in the content analysis, because these participants submitted at least seven journal entries and gave permission to use their journals in the research.

In the first stage of the study, it was considered how often the concept of sustainability and related concepts are reflected in the journals of participants compared to the documents that are specifically related to sustainability education used in the blended learning course on the topic of sustainable education pedagogy (Table 1):

- Future Fit (Sterling, 2012);

- Learning for the Future' (Learning for the..., 2012);

- Green Pedagogy (Green pedagogy..., 2018).

Table 1

Comparing the top 20 concepts of the learning journals to the top 20 concepts of three key texts in the ProfESus course

\begin{tabular}{clcclcc}
\hline Rank & \multicolumn{1}{c}{$\begin{array}{c}\text { ESD concepts from 3 key } \\
\text { texts }\end{array}$} & Hits & $\begin{array}{c}\text { \% } \\
\text { Relevance }\end{array}$ & $\begin{array}{c}\text { Learning Journal } \\
\text { concepts }\end{array}$ & Hits & $\begin{array}{c}\text { \% } \\
\text { Relevance }\end{array}$ \\
\hline 1 & development & 543 & $100 \%$ & students & 250 & $93 \%$ \\
2 & students & 534 & $98 \%$ & sustainable & 179 & $66 \%$ \\
3 & sustainable & 524 & $97 \%$ & time & 165 & $61 \%$ \\
4 & learning & 474 & $87 \%$ & work & 150 & $56 \%$ \\
5 & ESD & 458 & $84 \%$ & sustainability & 134 & $50 \%$ \\
6 & education & 424 & $78 \%$ & change & 129 & $48 \%$ \\
7 & work & 356 & $66 \%$ & school & 127 & $47 \%$ \\
8 & SD & 292 & $54 \%$ & waste & 125 & $46 \%$ \\
9 & teacher & 280 & $52 \%$ & thinking & 124 & $46 \%$ \\
10 & process & 279 & $51 \%$ & use & 122 & $45 \%$ \\
11 & sustainability & 279 & $51 \%$ & different & 120 & $44 \%$ \\
12 & teaching & 275 & $51 \%$ & people & 115 & $43 \%$ \\
13 & research & 273 & $50 \%$ & things & 102 & $38 \%$ \\
14 & project & 266 & $49 \%$ & teaching & 100 & $37 \%$ \\
15 & knowledge & 260 & $48 \%$ & food & 100 & $37 \%$ \\
16 & social & 252 & $46 \%$ & learning & 99 & $37 \%$ \\
17 & teachers & 242 & $45 \%$ & course & 97 & $36 \%$ \\
18 & different & 218 & $40 \%$ & example & 96 & $36 \%$ \\
19 & action & 200 & $37 \%$ & important & 95 & $35 \%$ \\
20 & school & 200 & $37 \%$ & values & 92 & $34 \%$ \\
\hline
\end{tabular}

All key concepts are more or less related to teaching and learning, since the participants are educators or trainers. Table 1 shows that eight key concepts of the top 20 in both lists are directly connected to the 
main aim of the blended learning course, namely sustainable and sustainability, moreover, they were used equally frequently by course participants and key authors.

In the second stage of the study, it was clarified which concepts are strongly linked to the concepts sustainable and sustainability (Table 2). Leximancer software (Leximancer software, 2019) was used to process the data from the learning journals and create these linked sets of concepts.

Table 2

The top 20 concepts most linked to concepts sustainable and sustainability

\begin{tabular}{|c|c|c|c|c|c|c|}
\hline Rank & $\begin{array}{l}\text { Concepts most } \\
\text { associated with } \\
\text { sustainable }\end{array}$ & Hits & $\begin{array}{c}\text { Relevance, } \\
\%\end{array}$ & $\begin{array}{l}\text { Concepts most } \\
\text { associated with } \\
\text { sustainability }\end{array}$ & Hits & $\begin{array}{c}\text { Relevance, } \\
\%\end{array}$ \\
\hline 1 & mindset & 57 & 71 & topic & 11 & 22 \\
\hline 2 & teaching & 24 & 24 & using & 9 & 17 \\
\hline 3 & thinking & 28 & 23 & teacher & 9 & 16 \\
\hline 4 & able & 16 & 22 & important & 14 & 15 \\
\hline 5 & world & 16 & 22 & course & 14 & 14 \\
\hline 6 & change & 25 & 19 & world & 10 & 14 \\
\hline 7 & day & 11 & 18 & work & 20 & 13 \\
\hline 8 & course & 17 & 18 & system & 6 & 13 \\
\hline 9 & sidea & 10 & 16 & sidea & 8 & 13 \\
\hline 10 & topic & 8 & 16 & feel & 7 & 12 \\
\hline 11 & better & 10 & 16 & project & 7 & 12 \\
\hline 12 & education & 10 & 16 & group & 8 & 11 \\
\hline 13 & real & 6 & 15 & thinking & 14 & 11 \\
\hline 14 & future & 11 & 15 & able & 8 & 11 \\
\hline 15 & students & 34 & 14 & better & 7 & 11 \\
\hline 16 & environment & 6 & 13 & ideas & 7 & 11 \\
\hline 17 & school & 16 & 13 & future & 8 & 11 \\
\hline 18 & staff & 5 & 12 & others & 5 & 11 \\
\hline 19 & learning & 12 & 12 & time & 17 & 10 \\
\hline 20 & teachers & 6 & 12 & interesting & 7 & 10 \\
\hline
\end{tabular}

The data in the Table 2 confirm that the most tightly connected concept with sustainable is mindset. This is a clear indication that the course has linked the sustainability topic to the need for competence in this, i.e. knowledge of sustainability is not sufficient on its own but must be accompanied by an associated mindset (Fox, Iriste, Bezeljak, 2019).

The concept sustainability is more tightly linked to the educational context, while the concept sustainable - to education and learning.

Certain parallels can be drawn with E. McConnell Freeman (McConnell Freeman, 2011) analysis of sustainability definitions, where four main areas are highlighted:

- education - it should be understood as the training of hospitality managers who take responsibility for educating their clients;

- process as opposed to product - hospitality managers should be aware that sustainability is not a product that can be achieved/produced overnight, but a complex, dynamic, long-term process;

- community involvement and participation - hospitality businesses that do not implement sustainable development initiatives may be under public pressure to make changes;

- future conditions - hospitality managers should be proactive in order to avoid creating negative circumstances in the future. 
At the final stage of the study, reflections on sustainability over the lifespan of the blended learning course were compared. How the main concepts changed over time were observed by comparing journal entries at the beginning of the course, Figure 4, to those from the end of the course, Figure 5.

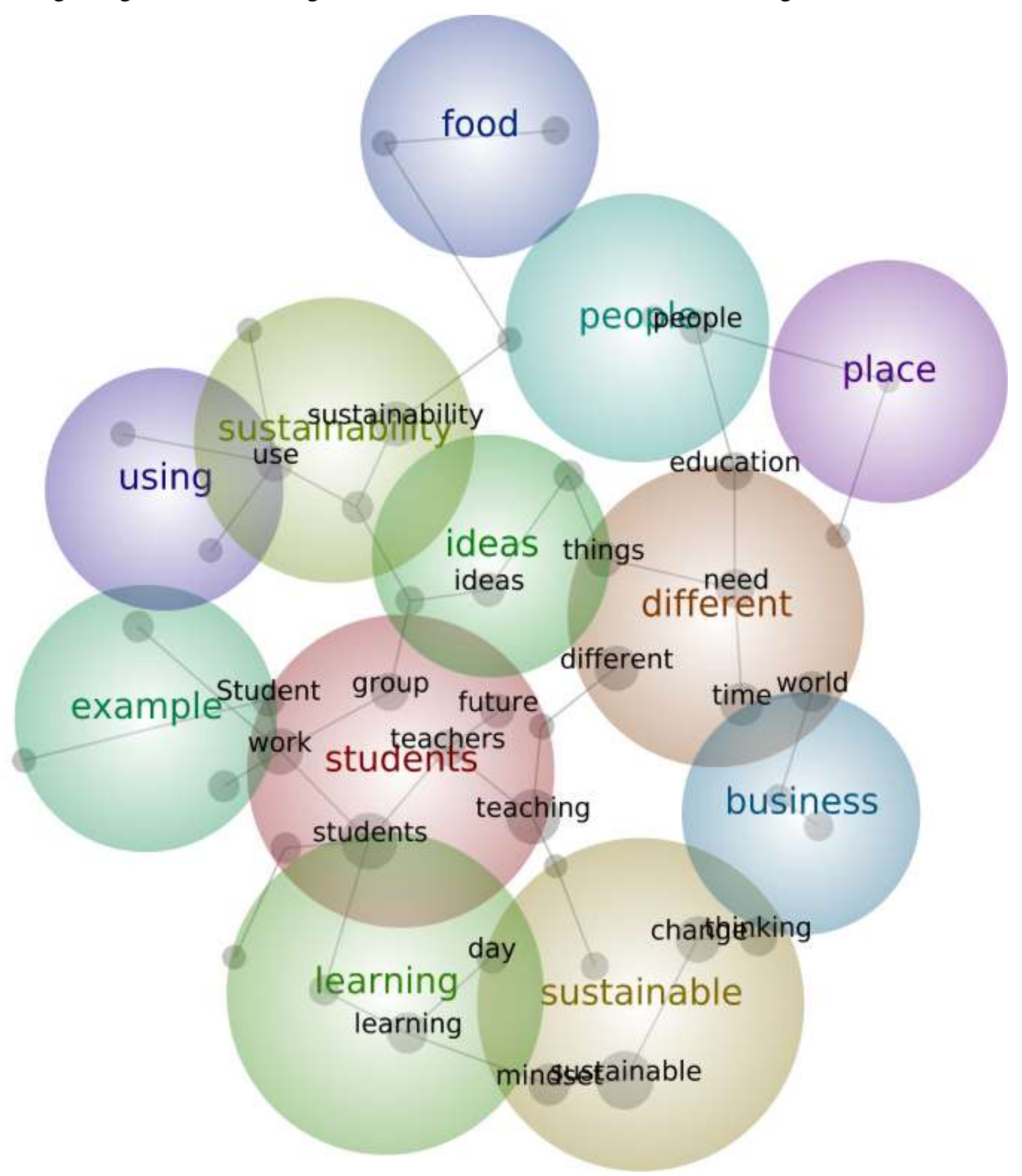

Figure 4. Early observations theme map (Fox, Iriste, Bezeljak, 2019).

There are considerable differences between the two theme maps, namely that at the beginning of the course more attention was paid to everyday processes, pedagogy and organisations, then at the end of the course participants focused on specific aspects of sustainability - plastics, waste, tobacco. 


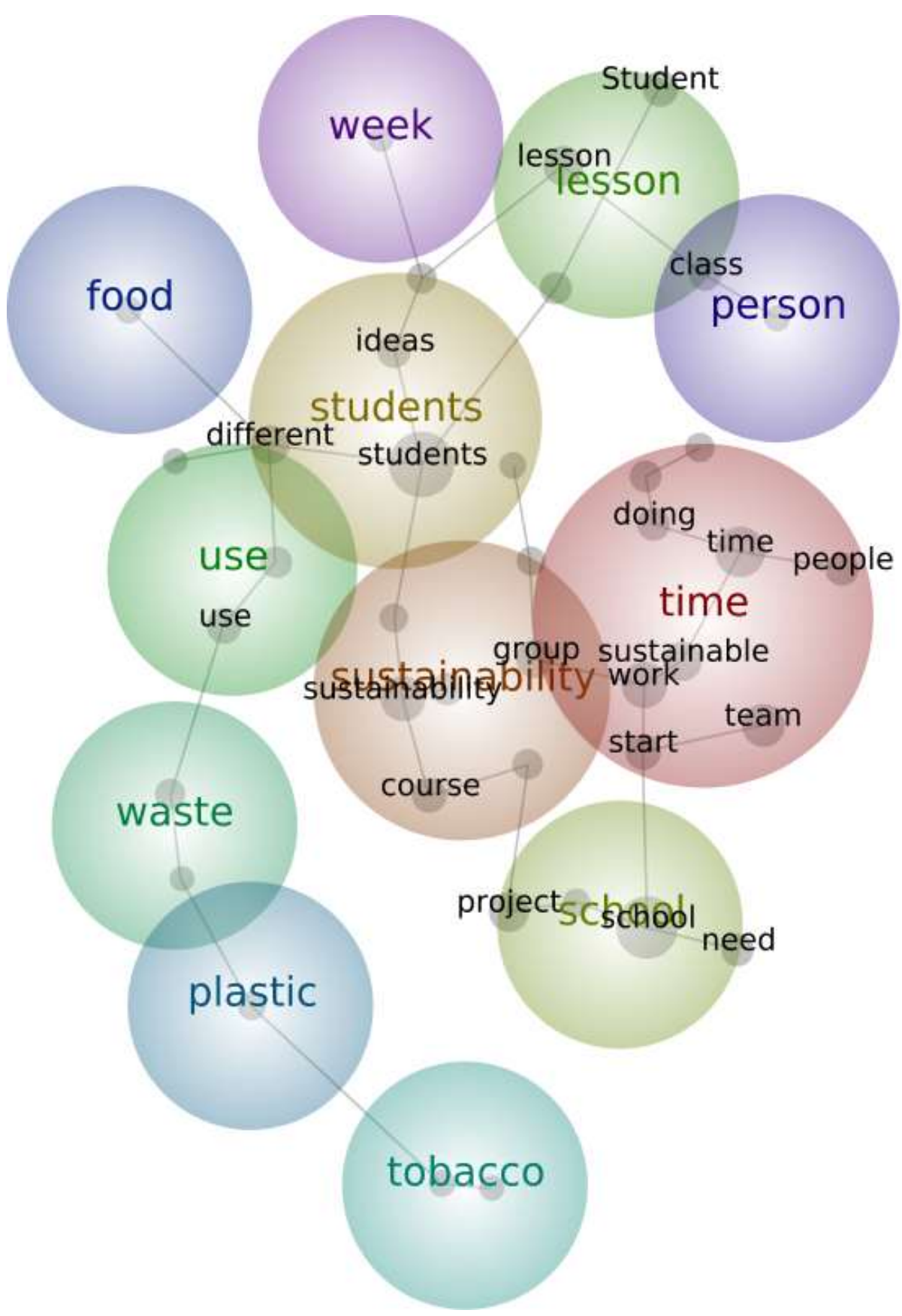

Figure 5. Late observations theme map (Fox, Iriste, Bezeljak, 2019).

This could be an indication of a more nuanced understanding of the concept of sustainability over time although it does not provide evidence of actual increased sustainable behaviour, which encompasses the sustainable mindset. As indicated by a group of scientists from the United States (Lane, Maznevski, Mendenhall, 2017), discovering is about learning and creating. It includes a set of transformation processes that culminate in new visions and actions that, in turn, lead to the creation of new knowledge, competence, actions and things (Iriste, Katane, 2019). Continual discovering helps to adapt to a permanent flow in the global market, including hospitality.

\section{Conclusions}

- A sustainable mindset is a set of rules (often - unwritten), attitudes, values that promote automatic reactions, by default, particularly in the work environment. At the same time, a sustainable mindset is not just a result, it is a continuous process as awareness of sustainability is constantly changing. 
- Comparing the top 20 concepts of the learning journals to the top 20 concepts of three key texts in the ProfESus course shows they were used equally frequently.

- There are considerable differences between the two theme maps at the beginning of the course and at the end of the course when participants focused on specific aspects of sustainability. This could be an indication of a more nuanced understanding of the concept of sustainability over time although it does not provide evidence of actual increased sustainable behaviour, which encompasses the sustainable mindset. The text analysis is less useful in showing increased sustainability awareness over time. This question may be better answered using other methods. An indicator of sustainable development awareness can be monitored through a high ranking of the sustainable development concepts: mindset, values and UNECE competences.

- Educators learning journals are a rich source of feedback on the efficacy of the blended learning course "Discovering a sustainable mindset for future-oriented professionals in guest-oriented businesses" and can be used as a part of the quality assurance process to improve the course.

- Content analysis tools, such as the Leximancer software used in this study, are a useful way of drawing more objective conclusions about the way educators react to the meta-level of training than by relying on human interpretation alone.

\section{Bibliography}

1. Cseh M., Davis E.B., Khilji S.E. (2013). Developing a global mindset: Learning of global leaders. European Journal of Training and Development, 37(5), 489-499. doi: 10.1108/03090591311327303

2. Fox A.E.M., Iriste S., Bezeljak P. (2019). Detecting a Sustainable Mindset through Using Content Analysis of Teacher-produced Learning Journals. Journal of Teacher Education for Sustainability, 21(1), 35-47. doi: 10.2478/jtes-2019-0003

3. Green pedagogy: From theoretical basics to practical sustainable learning activities. (2018). Vienna: University College for Environmental and Agrarian Pedagogy (UCEAP). Retrieved from https://www.haup.ac.at/wp-content/uploads/2019/10/Green-Pedagogy.pdf

4. Harris P. (2018). The Hidden Benefits of a Sustainable Mindset. Retrieved from https://www.3blmedia.com/News/Hidden-Benefits-Sustainable-Mindset

5. Iriste S., Katane I. (2019). Prospective Hospitality Business Managers' Sociocultural Competence within the Context of Social and Cultural Environments. In V. Dislere (Ed.), The Proceedings of the International Scientific Conference Rural Environment. Education. Personality (REEP), 12. Jelgava: Latvia University of Life Sciences and Technologies, 48-56. doi: 10.22616/REEP.2019.006

6. Kassel K., Rimanoszy I., Mitchel S.F. (2016). The Sustainable Mindset: Connecting Being, Thinking, and Doing in Management Education. In G Atinc (Ed.), Proceedings of Academy of Management Annual Meeting, 1, 1-39. doi: 10.5465/ambpp.2016.16659abstract

7. Kuhn T.S. (2012). The structure of scientific revolutions $\left(4^{\text {th }}\right.$ ed.). London: The University of Chicago Press.

8. Lane H.W., Maznevski M.L., Mendenhall M.E. (2017). Globalization: Hercules meets Buddha. In H.W. Lane, M.L. Maznevski, M.E. Mendenhall, J.M. McNett (Eds.), The Blackwell Handbook of Global Management. Oxford: Blackwell Publishing Ltd, 1-25. Retrieved from https://onlinelibrary.wiley.com/doi/book/10.1002/9781405166355

9. Laufenberg-Beermann A., Michenthaler J., Fox A., Iriste S., Kettunen J., Ruggeri F., Shishova D., Temisevä S., Wogowitsch C. (2019). ProfESUS Handbook. Professional Education for Sustainability. Vienna: University College for Environmental and Agrarian Pedagogy (UCEAP). Retrieved from https://profesus.eu/fileadmin/user_upload/Outputs/English/ProfESus_Handbook_web.pdf

10. Learning for the future: Competences in Education for Sustainable Development. (2012). United Nations Economic Commission for Europe Strategy for Education for Sustainable Development Retrieved from

http://www.unece.org/fileadmin/DAM/env/esd/ESD_Publications/Competences_Publication.pdf

11. Letch N. (2012). Using reflective journals to engage students in learning business process management concepts. Knowledge Management \& E-Learning: An International Journal, 4(4), 435-454. doi: 10.34105/j.kmel.2012.04.033 
12. Leximancer software. (2019). Retrieved from https://info.leximancer.com/

13. McConnell Freeman E. (2011). Restaurant Industry Sustainability: Barriers and Solutions to Sustainable Practice Indicators (Master Thesis, Arizona: Arizona State University). Retrieved from https://repository.asu.edu/attachments/56588/content/Freeman_asu_0010N_10634.pdf

14. Merriam-Webster Dictionary. (2016). Sustainable Mindset Retrieved from https://www.merriamwebster.com/dictionary/mind-set

15. O'Riordan T. (1997). Climate Change 1995: Economic and Social Dimensions. Environment, 39(9), 34-39. doi: 10.1080/00139159709604768

16. Ott K. (2003). The Case for Strong Sustainability. In K. Ott, P.P. Thapa (Eds.), Greifswald's Environmental Ethics. Greifswald: Steinbecker Verlag Ulrich Rose. 59-64. Retrieved from https://www.academia.edu/279930/Greifswald_s_Environmental_Ethics._From_the_work_of_th e_Michael_Otto_Professorship_at_Ernst_Moritz_Arndt_University_1997_2002

17. Peet J. (2009). Strong Sustainability for New Zealand: Principles and Scenario. Principles and scenarios. New Zealand: Nakedize Ltd. Retrieved from https://earthcharter.org/invent/images/uploads/Strong\%20sustainability\%20for\%20NZ\%20(2).pdf

18. Scharmer O., Kaufer K. (2013). Leading from the Emerging Future: From Ego-System to Eco-System Economies. Oakland: Berrett-Koehler Publishers. Retrieved from https://www.ottoscharmer.com/sites/default/files/e2e_ulab.pdf

19. Sterling S. (2011). Transformative Learning and Sustainability: sketching the conceptual ground. Learning and Teaching in Higher Education, 5, 17-33. Retrieved from http://dl.icdst.org/pdfs/files/0cd7b8bdb08951af53e5927e86938977.pdf

20. Sterling S. (2012). The Future fit framework: An introductory guide to teaching and learning for sustainability in HE. Plymouth: Higher Education Academy. Retrieved from http://www.earthethicsinstitute.org/Resources/SustEd_Sterling_The_Future_Fit_Framework.pdf

21. Story J.S.P., Barbuto J.E. Jr., Luthans F., Bovaird J.A. (2014). Meeting the Challenges of Effective International HRM: Analysis of the Antecedents of Global Mindset. Human Resource Management, 53(1), 131-155. doi: 10.1002/hrm.21568 